\title{
Comparing Child Laborers and Not-Working Children: Subjective Well-Being, Engagement and Motivation to Study
}

\author{
Ali Eryilmaz \\ Yildiz Technical University Educational Faculty, Counseling Psychology \\ Department, Turkey \\ Rıdvan Kumek \\ Ministry of Education, Turkey \\ Hafiz Bek \\ Usak University Educational Faculty, Counseling Psychology Department, \\ Turkey
}

Doi:10.19044/ejes.v7no2a10 URL:http://dx.doi.org/10.19044/ejes.v7no2a10

\begin{abstract}
The aim of this study is to compare children who are child laborers and those not working in terms of subjective well-being, engagement and motivation, and levels of liking school. The study group consisted of 120 male students (60 students were child laborers; the other students did not work) in two secondary schools. In this study, the motivation to study scale, the class engagement scale, and the subjective well-being scale were used. The Mann Whitney-U Test and Kruskal Wallis Variance Analysis Test were used to analyze the data. In this study, differences were found between the child labor group and non-working groups of students in terms of motivation to study, engagement in class and subjective well-being. With respect to child labor, it was found that as the liking of school increased, the subjective well-being, class engagement and motivation to study levels increased. Conversely, with respect to not-working children, it was found that as the liking of school, class engagement and motivation to study levels increased.
\end{abstract}

Keywords: Child labor, school liking, engagement, motivation, well-being.

\section{Introduction}

Article Individuals experience various stages of development along the way to becoming an adult (Erikson, 1968). Childhood is one of these developmental periods. Specifically, individuals between the ages of 3 and 18 are defined as children (Santrock, 2006; Woodhead, 1999). Children should 
be supported physiologically, psychologically and socially for their healthy development (Santrock, 2006). However, some children might not be sufficiently supported for healthy development and might even be expected to support others. These children are defined as working children - child labor. Child laborers are both vulnerable and might not experience a healthy development process (Fyfe, 1989; Woodhead, 1999). Studying child labor at this point might contribute to the literature.

Although there is not a complete understanding of the concept of child labor, there are various definitions of child labor. For instance, Bulut and Gülcan (2007) describe child labor as children who work with any craftsman or work in a variety of industries or in agriculture, alone or with their family. In general, when an evaluation is made, it can be concluded that working children are mostly living in poor or developing countries (Ray, 2000). Child laborer families are poor, and the children work to bring income to the family (Walkerdine, 2005). There are many reasons for being a child laborer, including the presence of a crowded population, lack of educational opportunities, poverty, migration and the economic value of the child in the traditional sense rather than the psychological value (Fyfe, 1989; Tor, 2010).

When overall evaluations are made, the conclusions are that the educational, psychological and social needs of child laborers must be satisfied. According to the results of the studies, the fact that child laborers are away from the academic environment (Ravallion $\&$ Wodon, 2000) causes them to have health problems and experiences decreases in their level of well-being (Estacio \& Marks 2005). Additionally, there have been negative effects from being a child laborer, such as security problems, economic exploitation, accidents and injuries, and school problems (Woodhead, 1999).

The literature reveals that indirect and direct research results indicate that the well-being of child laborers is adversely affected. For example, poor child laborers are negatively affected by poverty (Biggeri \&Mehrotra, 2011). The level of well-being of child laborers decreases due to their working (Biggeri, Libanora, Mariani \& Menchini, 2006). Studies show that child laborers experience poor working conditions, poor treatment and abuse in the working environment, and serious levels of injury due to accidents and injuries (Woodhead, 1999). In Turkey, there are studies on the subjective well-being of children who do not work at a job (Eryılmaz, 2011, 2012; Uçan \& Esen, 2015; Tagay \& Baltac1, 2017). No studies compare the subjective well-being of children who do not work in a job with that of children working in a job. In particular, more work is done on children working in the street in Turkey (Bilgin, 2009; Erdoğdu \& Oto, 2004; Yılmaz, Göçen \& Yılmaz, 2012). Conversely, there are very few studies on children who continue their education and work part-time. Neither worldwide (Hobbs \& Cornwell, 1986) nor in Turkey are these issues examined in detail. 
Studies on child labor show that being a working child adversely affects a child's educational life. For both child laborers and non-working children, there are two important factors in motivation and engagement in educational experiences. Motivation affects the power, direction and energy of children's studies. High motivation is also necessary for student achievements (Covington, 1998; Martin, 2003; Eccles, 1983; Wigfield, 1994). In addition to motivation, student engagement (cognitive, behavioral and emotional) in the course of learning is also effective in their success and in their learning of a subject (Fredricks, Blumenfeld \& Paris, 2004; Li \& Lerner 2011; Skinner, Furrer, Marchand \& Kindermann, 2008). Child laborers are absent because they must go to work. Due to this situation, their level of attendance in school and class decreases (Beegle, Dehejia \& Gatti, 2009; Binder \& Scrogin, 1999; Dorman, 2008; Heady, 2003). In the literature, there are no direct studies in terms of motivation status to study lesson motivation (intrinsic, extrinsic and amotivation) and engagement (cognitive, behavioral and emotional) of children who are child laborers and not-working children.

Being child laborers causes children to be neglected in terms of education. Studies have revealed that working in a job takes the children away from school and causes them to spend less time at school (Beegle, Dehejia, \& Gatti, 2009; Binder, \& Scrogin, 1999; Dorman, 2008; Heady, 2003). The results of these studies reveal the importance of bringing children closer to school. There can be organizational arrangements to bring children closer to school, such as poverty reduction. At the same time, child-related variables might be an important factor in children's approach to school. For instance, the child liking school and being interested in the lessons are important factors in helping the child laborer to attach to the school (Goulart \& Bedi, 2008). However, in the literature, the number of studies comparing children who are child laborers and not-working children in terms of attitudes toward school is very small.

It is also important to address school-related factors in child labor research because continuing education is an important tool in preventing child labor (Rossi \& Rosati, 2007). However, child laborers might not all have similar attitudes toward school. At this point, levels of liking school should also be examined in studies. No studies have been found comparing children who are child laborers and not-working children in terms of subjective wellbeing, engagement and motivation with levels of liking school. The aim of this study is to compare children who are child laborers and not-working children in terms of subjective well-being, engagement and motivation with levels of liking school. 


\section{Method}

\section{Research Design}

The aim of this study is to compare children who are child laborers and those not working in terms of subjective well-being, class engagement and motivation to study with levels of liking school. The study was conducted using cross-sectional models. The study sought answers to the following questions:

1. Is there a significant difference between children who are child laborers and not-working children in terms of subjective well-being, engagement (cognitive, behavioral and emotional) in class, and motivation to study (intrinsic, extrinsic and amotivation)?

2. Do working children's subjective well-being, class-engagement (cognitive, behavioral and emotional), motivation to study (intrinsic, extrinsic and amotivation) differ significantly in terms of level of school liking?

3. Do not-working children's subjective well-being, class-engagement (cognitive, behavioral and emotional), motivation to study (intrinsic, extrinsic and amotivation) differ significantly in terms of level of school liking?

In the study, data were collected one application at a time. The study examined whether the sample met the parametric conditions in terms of variables. In this respect, the normality assumption (Kolmogrov Simigrov Test, Shapiro Wilks Test) and homogeneity of variances (Levene Test) were tested. The results showed that the sample did not meet the parametric conditions in terms of variables. In the light of these analyses, the first question of the study was analyzed with the Mann Whitney-U Test. Kruskal Wallis Variance Analysis was used for the second and third questions. A set of exclusion criteria was also established in the study. First, for child laborers in addition to students working part-time in a job, the condition of continuing schooling was sought. Additionally, for not-working children, only the condition of continuing schooling was sought. Not having received any psychiatric diagnosis was also required of both groups. Particularly for the child laborers, inclusion criteria such as working for half a day after school, being paid for their work, and not working occasionally were established. Lastly, the districts in which the students of the study group (child laborers and not-working children) live are districts in which families with low socioeconomic status live. The income level of the children included in the study was lower than 2000 (nearly 333 Dollars) Turkish Liras as a criterion for inclusion in the study. 


\section{Study Group}

The study group consisted of 120 male students (60 students were child laborers; the others did not work) in two secondary schools in Istanbul. Of the students in the study, $78(65 \%)$ were in the 7 th grade and the remaining 42 (35\%) were in the 8th grade. Thirty-nine of the seventh graders were part-time working students (child labor), and 39 of them did not work in a job. Twentyone of the eighth graders were part-time working students (child labor), and 21 of them did not work in a job. The age range was between 11 and 15 (mean $=12.76$; standard deviation $=0.89)$. When we examined the distribution by age, $7(5.8 \%)$ students were 11 years old, $41(34.2 \%)$ students were 12 years old, $48(40 \%)$ students were 13 years old, 21 (17.5\%) students were 14 years old, and $3(2.5 \%)$ students were 15 years old. The districts in which the students of the study group live are districts in which families with low socioeconomic status live.

\section{Instruments}

The scale of motivation to study: This four-point Likert-type scale consisting of thirteen items was developed by Eryllmaz and Ercan (2014). The reliability coefficient (Cronbach's alpha) for the whole scale was found to be 0.80. It consists of 3 sub-dimensions. These sub-dimensions are "intrinsic motivation", "extrinsic motivation" and "amotivation". The Cronbach's alpha value of the intrinsic motivation sub-dimension was 0.81 , the Cronbach's alpha value of the extrinsic motivation sub-dimension was 0.84 , and the Cronbach's alpha of the amotivation sub-dimension was 0.75 .

Adolescent subjective well-being scale: The adolescent subjective well-being scale was developed by Eryilmaz (2009). The scale is a four-point Likert type and consists of 15 items. The Cronbach's alpha value was found to be 0.86 for the whole scale. The scale consists of 4 sub-dimensions: "Satisfaction with family relationships", "positive affection", "life satisfaction", and "satisfaction with relationships via significant others". The Cronbach's alpha value of the satisfaction with family relationships subdimension was 0.83, the Cronbach's alpha value of the satisfaction with relationships via significant others was 0.73 , the Cronbach's alpha value of the life satisfaction subscale was 0.81 , and the Cronbach's alpha value of the positive affection sub-dimension was 0.66 .

Class engagement scale: This scale was developed by Ery1lmaz (2014). The scale of class engagement consists of 15 items that are answered as "not suitable at all", "not suitable", "a little appropriate", "appropriate", and "completely appropriate". The scale consists of three dimensions: emotional engagement, cognitive engagement and behavioral engagement. The Cronbach's alpha value of the total points of the scale was determined to be 0.92. The Cronbach's alpha value of the emotional engagement sub-dimension 
was 0.84 , the Cronbach's alpha value of the behavioral engagement subdimension was 0.86 , and the Cronbach's alpha value of the cognitive engagement sub-dimension was 0.84 .

\section{Findings}

\section{Comparison of the child laborers and not-working children}

In this study, the child laborers and not-working children were initially compared in terms of subjective well-being, class engagement (cognitive, behavioral and emotional) in class, and motivation to study (intrinsic, extrinsic and amotivation). The Mann-Whitney $U$ test technique was used in the comparison. The results are given in Table 1.

Table 1. Descriptive statistics and results of Mann Whitney U test 


\begin{tabular}{|c|c|c|c|c|c|c|c|c|}
\hline \multicolumn{2}{|c|}{ Variables } & $\begin{array}{l}\text { Condition of being } \\
\text { child labour }\end{array}$ & \multirow{2}{*}{$\frac{\mathrm{n}}{60}$} & \multirow{2}{*}{$\frac{\bar{x}}{14,03}$} & $\mathrm{Sd}$ & $\begin{array}{l}\text { Mean } \\
\text { ranks }\end{array}$ & $\mathrm{U}$ & Z \\
\hline 1. & SW & Child labours & & & 2,93 & 54,73 & 1453.50 & $-1.96^{*}$ \\
\hline & & $\begin{array}{l}\text { Not } \\
\text { children }\end{array}$ & 60 & 14,70 & 2,47 & 66,28 & & \\
\hline \multirow[t]{2}{*}{2.} & \multirow[t]{2}{*}{$\mathrm{PE}$} & Child labours & 60 & 12,10 & 3,17 & 53,16 & 1359.50 & $-2.33^{*}$ \\
\hline & & $\begin{array}{l}\text { Not } \\
\text { children }\end{array}$ & 60 & 13,42 & 2,37 & 67,84 & & \\
\hline \multirow{2}{*}{$\begin{array}{l}3 . \\
\text { RSO }\end{array}$} & \multirow[t]{2}{*}{ SW } & Child labours & 60 & 13,02 & 2,96 & 54,96 & 1467.50 & -1.79 \\
\hline & & $\begin{array}{ll}\text { Not } & \text { working } \\
\text { children } & \end{array}$ & 60 & 13,90 & 2,90 & 66,04 & & \\
\hline 4. & \multirow[t]{2}{*}{ SW } & Child labours & 60 & 8,85 & 2,63 & 54,27 & 1426.00 & $-1.99 *$ \\
\hline $\mathrm{L}$ & & $\begin{array}{ll}\text { Not } & \text { working } \\
\text { children } & \end{array}$ & 60 & 9,81 & 2,03 & 66,73 & & \\
\hline \multirow[t]{2}{*}{$\begin{array}{l}5 . \\
\text { SWB }\end{array}$} & \multirow[t]{2}{*}{$\mathrm{TP}$} & Child labours & 60 & 48,01 & 9,95 & 52,32 & 1309.00 & $-2.58 *$ \\
\hline & & $\begin{array}{l}\text { Not working } \\
\text { children }\end{array}$ & 60 & 51,85 & 8,44 & 68,68 & & \\
\hline \multirow[t]{2}{*}{6.} & \multirow[t]{2}{*}{$\mathrm{EE}$} & Child labours & 60 & 18,22 & 5,15 & 51,39 & 1253.50 & $-2.88 * *$ \\
\hline & & $\begin{array}{ll}\text { Not } & \text { working } \\
\text { children } & \end{array}$ & 60 & 20,81 & 4,16 & 69,61 & & \\
\hline \multirow[t]{2}{*}{7.} & \multirow[t]{2}{*}{$\mathrm{BE}$} & Child labours & 60 & 18,21 & 5,16 & 51,58 & 1264.50 & $-2.82 *$ \\
\hline & & $\begin{array}{ll}\text { Not } & \text { working } \\
\text { children } & \end{array}$ & 60 & 20,71 & 4,24 & 69,43 & & \\
\hline \multirow[t]{2}{*}{8.} & \multirow[t]{2}{*}{$\mathrm{CE}$} & Child labours & 60 & 17,74 & 5,24 & 51,23 & 1244.00 & $-2.92 * *$ \\
\hline & & $\begin{array}{ll}\text { Not } & \text { working } \\
\text { children } & \end{array}$ & 60 & 20,46 & 4,09 & 69,77 & & \\
\hline \multirow[t]{2}{*}{$\begin{array}{l}9 . \\
\text { CE }\end{array}$} & \multirow[t]{2}{*}{$\mathrm{TP}$} & Child labours & 60 & 54,18 & 14,54 & 50,47 & 1198.00 & $-3.16 * *$ \\
\hline & & $\begin{array}{ll}\text { Not } & \text { working } \\
\text { children } & \end{array}$ & 60 & 61,98 & 11,71 & 70,53 & & \\
\hline \multirow[t]{2}{*}{10.} & \multirow[t]{2}{*}{ IM } & Child labours & 60 & 18,91 & 4,25 & 53,58 & 1384.00 & $-2.95^{*}$ \\
\hline & & $\begin{array}{ll}\text { Not } & \text { working } \\
\text { children } & \end{array}$ & 60 & 20,42 & 3,49 & 67,43 & & \\
\hline \multirow[t]{2}{*}{11.} & \multirow[t]{2}{*}{ EM } & Child labours & 60 & 11,81 & 2,80 & 56,55 & 1563.00 & -1.25 \\
\hline & & $\begin{array}{ll}\text { Not } & \text { working } \\
\text { children } & \end{array}$ & 60 & 12,42 & 2,83 & 64,45 & & \\
\hline \multirow[t]{2}{*}{12.} & \multirow[t]{2}{*}{ A } & Child labours & 60 & 6,33 & 2,62 & 69,77 & 1244.00 & $-2.97 * *$ \\
\hline & & $\begin{array}{ll}\text { Not } & \text { working } \\
\text { children } & \end{array}$ & 60 & 5,05 & 2,57 & 51,23 & & \\
\hline
\end{tabular}

Note: $* \mathrm{p}<.05 * * *^{2}<.01 ; 1$. SWFR: Satisfaction with family relationships; 2 .

PE: Positive affection; 3. SWRSO: Satisfaction with relationships via significant others; 4. SWL: Satisfaction with life; 5. TPSWB: Total point of subjective well-being; 6. EE: Emotional engagement ;7. BE: Behavioural engagement; 8. CE: Cognitive engagement; 9. Total point of class- 
engagement; 10. IM: Intrinsic motivation; 11. EM: Extrinsic motivation; 12. A: Amotivation

As shown in Table 1, the Mann-Whitney $U$ test was used to examine whether the scores of the scales (subjective well-being, class engagement and motivation to study) used in the study showed a significant difference between child laborers and not-working children. The results indicated that there was a significant difference between child laborers' mean ranks (54.73) and notworking children mean ranks (66.28) with respect to satisfaction with family relationships $(\mathrm{U}=1453.50, \mathrm{Z}=-1.96 ; \mathrm{p}<.05)$. There was a significant difference between child laborers' mean ranks (53.16) and not-working children mean ranks (67.84) with respect to positive affection ( $U=1359.50$, $\mathrm{Z}=-2.33 ; p<.05)$. There was a significant difference between child laborers' mean ranks (54.27) and not-working children's mean ranks (66.73) with respect to satisfaction with life $(\mathrm{U}=1426.50, \mathrm{Z}=-1.99 ; p<.05)$. There was a significant difference between child laborers' mean ranks (52.32) and notworking children's mean ranks (68.68) with respect to total points of subjective well-being $(\mathrm{U}=1309.50, \mathrm{Z}=-2.58 ; p<.05)$. A significant difference existed between child laborers' mean ranks (51.39) and not-working children's mean ranks (69.61) with respect to emotional engagement (U=1253.50, $\mathrm{Z}=-2.88 ; p<.01)$. There was a significant difference between child laborers' mean ranks (51.58) and not-working children's mean ranks (69.43) with respect to behavioral engagement ( $U=1264.50, \mathrm{Z}=-2.82 ; p<.05)$. A significant difference existed between child laborer's mean ranks (51.23) and not-working children's mean ranks (4.09) with respect to cognitive engagement $(\mathrm{U}=1244.00, \mathrm{Z}=-2.92 ; p<.01)$. There was a significant difference between child laborers' mean ranks (50.47) and not-working children's mean ranks (70.53) with respect to total points of class engagement $(U=1198.00$, $\mathrm{Z}=-3.16 ; p<.01)$. There was a significant difference between child laborers' mean ranks (4.25) and not-working children's mean ranks (3.49) with respect to intrinsic $(\mathrm{U}=1384.50, \mathrm{Z}=-2.95 ; p<.05)$. There was a significant difference between child laborers' mean ranks (2.62) and not-working children's mean ranks (2.57) with respect to amotivation ( $\mathrm{U}=1244.00, \mathrm{Z}=-2.97 ; p<.01)$. Additionally, there were no significant differences between child laborers' mean ranks and not-working children's mean ranks with respect to extrinsic motivation and satisfaction with relationships via significant others.

Investigation of Variables Depending upon School Liking Levels: In this study, whether laborer children's subjective well-being, class-engagement (cognitive, behavioral and emotional), motivation to study (intrinsic, extrinsic and amotivation) differ significantly in terms of level of school liking was examined by the Kruskal-Wallis test method. 


\section{Comparison of the child laborers in terms of level of school liking}

Table 2. Results of Kruskal-Wallis test for child labours

\begin{tabular}{|c|c|c|c|c|c|c|c|}
\hline Variables & $\begin{array}{l}\text { School } \\
\text { levels }\end{array}$ & liking $_{\mathrm{n}}$ & $\overline{\mathrm{x}}$ & $\mathrm{Sd}$ & $\begin{array}{l}\text { Mean } \\
\text { ranks }\end{array}$ & Median & $X^{2}$ \\
\hline \multirow{3}{*}{ 1.SWFR } & Some & 18 & 13,05 & 3,36 & 24,69 & 15,00 & 5,46 \\
\hline & Mostly & 23 & 14,18 & 2,59 & 29,39 & & \\
\hline & Too much & 19 & 14,78 & 2,78 & 37,34 & & \\
\hline \multirow[t]{3}{*}{ 2. PE } & Some & 18 & 10,18 & 3,26 & 19,78 & 13,00 & 10,61 ** \\
\hline & Mostly & 23 & 12,59 & 2,87 & 32,93 & & \\
\hline & Too much & 19 & 13,31 & 2,70 & 37,71 & & \\
\hline \multirow[t]{3}{*}{ 3.SWRSO } & Some & 18 & 11,38 & 3,20 & 21,58 & 14,00 & $7,06^{*}$ \\
\hline & Mostly & 23 & 13,86 & 2,47 & 34,91 & & \\
\hline & Too much & 19 & 13,56 & 2,77 & 33,61 & & \\
\hline \multirow[t]{3}{*}{ 4.SWL } & Some & 18 & 7,39 & 2,68 & 21,19 & 9,00 & $8,36^{*}$ \\
\hline & Mostly & 23 & 9,22 & 2,32 & 32,22 & & \\
\hline & Too much & 19 & 9,78 & 2,46 & 37,24 & & \\
\hline \multirow[t]{3}{*}{ 5.TPSWB } & Some & 18 & 42,02 & 10,58 & 19,19 & 50,00 & $11,39 * *$ \\
\hline & Mostly & 23 & 49,86 & 8,16 & 33,48 & & \\
\hline & Too much & 19 & 51,46 & 9,19 & 37,61 & & \\
\hline \multirow[t]{3}{*}{ 6.EE } & Some & 18 & 13,59 & 3,48 & 14,36 & 18,52 & $26,04 * *$ \\
\hline & Mostly & 23 & 18,81 & 4,69 & 32,54 & & \\
\hline & Too much & 19 & 21,89 & 3,57 & 43,32 & & \\
\hline \multirow[t]{3}{*}{ 7.BE } & Some & 18 & 13,55 & 4,05 & 14,64 & 19,00 & $22,68 * *$ \\
\hline & Mostly & 23 & 19,34 & 5,05 & 34,48 & & \\
\hline & Too much & 19 & 21,25 & 2,71 & 40,71 & & \\
\hline \multirow[t]{3}{*}{ 8.CE } & Some & 18 & 13,16 & 4,31 & 15,36 & 18,00 & $22,02 * *$ \\
\hline & Mostly & 23 & 18,56 & 4,74 & 33,09 & & \\
\hline & Too much & 19 & 21,09 & 3,41 & 41,71 & & \\
\hline \multirow[t]{3}{*}{ 9.TPCE } & Some & 18 & 40,31 & 10,56 & 13,56 & 56,00 & $27,07 * *$ \\
\hline & Mostly & 23 & 56,72 & 13,73 & 33,63 & & \\
\hline & Too much & 19 & 64,24 & 7,04 & 42,76 & & \\
\hline \multirow[t]{3}{*}{ 10.IM } & Some & 18 & 16,01 & 4,71 & 18,72 & 20,00 & $14,06^{* *}$ \\
\hline & Mostly & 23 & 19,41 & 3,96 & 31,91 & & \\
\hline & Too much & 19 & 21,06 & 2,36 & 39,95 & & \\
\hline \multirow[t]{3}{*}{ 11.EM } & Some & 18 & 9,49 & 3,03 & 16,33 & 12,00 & $19,08 * *$ \\
\hline & Mostly & 23 & 12,43 & 2,42 & 33,20 & & \\
\hline & Too much & 19 & 13,26 & 1,32 & 40,66 & & \\
\hline \multirow[t]{3}{*}{ 12.A } & Some & 18 & 6,99 & 2,73 & 34,61 & 6,00 & 1,57 \\
\hline & Mostly & 23 & 6,21 & 2,67 & 29,61 & & \\
\hline & Too much & 19 & 5,84 & 2,45 & 27,68 & & \\
\hline
\end{tabular}

Note: $* \mathrm{p}<.05 * * \mathrm{p}<.01 ; 1$. SWFR: Satisfaction with family relationships; 2 .

PE: Positive affection; 3. SWRSO: Satisfaction with relationships via significant others; 4. SWL: Satisfaction with life; 5. TPSWB: Total point of subjective well-being; 6. EE: Emotional engagement; 7. BE: Behavioural engagement; 8. CE: Cognitive engagement; 9. Total point of class- 
engagement; 10. IM: Intrinsic motivation; 11. EM: Extrinsic motivation; 12. A: Amotivation

As shown in Table 2, with respect to the positive emotion dimension, the Kruskal-Wallis test indicated that a significant difference existed between groups in which child laborers are involved in terms of school liking $(\chi 2=10.61, d f=2 ; p<.01)$. The Mann-Whitney U test was used to determine the difference between the groups. According to the results of the test $(U=112.00, p<.05)$, the difference was found to be between the group that likes (mean ranks $=19.78$ ) school somewhat and the group that mostly likes (mean ranks $=32.93$ ) school. Additionally, according to the results of the test $(U=73.00, p<.01)$, the difference was found to be between the group that like some (mean ranks $=19.78$ ) from school and the group that like too much (mean ranks $=37.71)$ from school. Moreover, according to the results of the test, no difference was found between the group that like mostly from schools and the group that likes school too much.

As shown in Table 2, with respect to the satisfaction with relationships via significant others dimension, the Kruskal-Wallis test indicated that a significant difference existed between groups in which child laborers are involved in terms of school liking $\left(\chi^{2}=7.06\right.$, d.f. $\left.=2, p<.05\right)$. The MannWhitney $U$ test was used to determine the difference between the groups. According to the results of the test $(U=114.00, p<.05)$, the difference was found to be between the group that like some (mean ranks $=21.58$ ) from school and the group that like mostly (mean ranks $=34.91)$ from school. Additionally, according to the results of the test $(U=103.50, p<.05)$, the difference was found to be between the group that like some (mean ranks = 21.58) from school and the group that like too much (mean ranks $=33.61$ ) from school. Moreover, according to the results of the test, no difference was found between the group that like mostly from schools and the group that like too much from school.

As shown in Table 2, with respect to the satisfaction with life dimension, the Kruskal-Wallis test indicated that a significant difference existed between groups in which child laborers are involved in terms of school liking $\left(\chi^{2}=8.36, d . f .=2, p<.05\right)$. The Mann-Whitney $\mathrm{U}$ test was used to determine the difference between the groups. According to the results of the test $(U=129.00, p<.05)$, the difference was found to be between the group that like some (mean ranks $=21.19$ ) from school and the group that like mostly (mean ranks $=32.22$ ) from school. Additionally, according to the results of the test $(U=81.50, p<.01)$, the difference was found to be between the group that like some (mean ranks $=21.19$ ) from school and the group that like too much (mean ranks $=37.24$ ) from school. Moreover, according to the results of the test, no difference was found between the group that like mostly from schools and the group that like too much from school. 
As shown in Table 2, with respect to the total points of subjective wellbeing dimension, the Kruskal-Wallis test indicated that a significant difference existed between groups in which child laborers are involved in terms of school liking $(\chi 2=11.39, d . f .=2, p<.01)$. The Mann-Whitney $\mathrm{U}$ test was used to determine the difference between the groups. According to the results of the test $(U=104.50, p<.01)$, the difference was found to be between the group that like some (mean ranks $=19.19$ ) from school and the group that like mostly (mean ranks $=33.48$ ) from school. Additionally, according to the results of the test $(U=70.00, p<.01)$, the difference was found to be between the group that like some (mean ranks $=19.19$ ) from school and the group that like too much (mean ranks $=37.61$ ) from school. Moreover, according to the results of the test, no difference was found between the group that like mostly from schools and the group that like too much from school.

As shown in Table 2, with respect to the emotional engagement dimension, the Kruskal-Wallis test indicated that a significant difference existed between groups in which child laborers are involved in terms of school liking $(\chi 2=26,04, d . f .=2, p<.01)$. The Mann-Whitney $\mathrm{U}$ test was used to determine the difference between the groups. According to the results of the test $(U=68.00, p<.05)$, the difference was found to be between the group that like some (mean ranks $=14.36$ ) from school and the group that like mostly (mean ranks $=32.54$ ) from school. Additionally, according to the results of the test $(U=19.50, p<.01)$, the difference was found to be between the group that like some (mean ranks $=14.36$ ) from school and the group that like too much (mean ranks $=43.32$ ) from school. Moreover, according to the results of the test, the difference was found $(U=126.50, p<.05)$ to be between the group that like mostly (mean ranks $=32.54$ ) from school and the group that like too much (mean ranks $=43.32$ ) from school.

As shown in Table 2, with respect to the behavioral engagement dimension, the Kruskal-Wallis test indicated that a significant difference existed between groups in which child laborers are involved in terms of school liking $(\chi 2=22.68, d . f .=2, p<.01)$. The Mann-Whitney $\mathrm{U}$ test was used to determine the difference between the groups. According to the results of the test $(U=76.00, p<.01)$, the difference was found to be between the group that like some (mean ranks $=14.64)$ from school and the group that like mostly (mean ranks $=34.48$ ) from school. Additionally, according to the results of the test $(U=16.50, p<.01)$, the difference was found to be between the group that like some (mean ranks $=14.64$ ) from school and the group that like too much (mean ranks $=40.71$ ) from school. Moreover, according to the results of the test, no difference was found between the group that like mostly from school and the group that like too much from school.

As shown in Table 2, with respect to the cognitive engagement dimension, the Kruskal-Wallis test indicated that a significant difference 
existed between groups in which child laborers are involved in terms of school liking $(\chi 2=22.02, d . f .=2, p<.01)$. The Mann-Whitney $\mathrm{U}$ test was used to determine the difference between the groups. According to the results of the test $(U=79.00, p<.01)$, the difference was found to be between the group that like some (mean ranks $=15.36)$ from school and the group that like mostly (mean ranks $=33.09$ ) from school. Additionally, according to the results of the test $(U=26.50, p<.01)$, the difference was found to be between the group that like some (mean ranks $=15.36$ from school and the group that like too much (mean ranks $=41.71$ ) from school. Moreover, according to the results of the test, no difference was found between the group that like mostly from school and the group that like too much from school.

As shown in Table 2, with respect to total points of class engagement, the Kruskal-Wallis test indicated that a significant difference existed between groups in which child laborers are involved in terms of school liking $(\chi 2=27.07, d . f .=2, p<.01)$. The Mann-Whitney $\mathrm{U}$ test was used to determine the difference between the groups. According to the results of the test $(U=67.00, p<.01)$, the difference was found to be between the group that like some (mean ranks $=13.56)$ from school and the group that like mostly (mean ranks $=33.63$ ) from school. Additionally, according to the results of the test $(U=6.00, p<.01)$. the difference was found to be between the group that like some (mean ranks $=13.56$ ) from school and the group that like too much (mean ranks $=42.76$ ) from school. Moreover, according to the results of the test, no difference was found between the group that like mostly from school and the group that like too much from school.

As shown in Table 2, with respect to intrinsic motivation, the KruskalWallis test indicated that a significant difference existed between groups in which child laborers are involved in terms of school liking $(\chi 2=14.06, d . f .=2$, $p<.01)$. The Mann-Whitney $\mathrm{U}$ test was used to determine the difference between the groups. According to the results of the test $(U=117.50, p<.05)$, the difference was found to be between the group that like some (mean ranks $=18.72$ ) from school and the group that like mostly (mean ranks $=31.91$ ) from school. Additionally, according to the results of the test $(U=48500, p<.01)$, the difference was found to be between the group that like some (mean ranks $=18.72$ ) from school and the group that like too much (mean ranks $=39.95$ ) from school. Moreover, according to the results of the test, no difference was found between the group that like mostly from school and the group that like too much from school.

As shown in Table 2, with respect to extrinsic motivation, the KruskalWallis test indicated that a significant difference existed between groups in which child laborers are involved in terms of school liking $(\chi 2=19.08, d . f .=2$, $p<.01)$. The Mann-Whitney $\mathrm{U}$ test was used to determine the difference between the groups. According to the results of the test $(U=85.50, p<.01)$, the 
difference was found to be between the group that like some (mean ranks = 16.33) from school and the group that like mostly (mean ranks $=33.20$ ) from school. Additionally, according to the results of the test $(U=37.50, p<.01)$, the difference was found to be between the group that like some (mean ranks $=16.33$ ) from school and the group that like too much (mean ranks $=40.66)$ from school. Moreover, according to the results of the test, no difference was found between the groups that like mostly from school and the group that like too much from school. Finally, with respect to amotivation and satisfaction with family relationships, no differences were found between the groups.

Comparison of the not-working children in terms of level of school liking Table 3. Results of Kruskal-Wallis test for not-working children

\begin{tabular}{|c|c|c|c|c|c|c|c|}
\hline Variables & $\begin{array}{l}\text { School } \\
\text { levels }\end{array}$ & liking $_{\mathrm{n}}$ & $\overline{\mathrm{x}}$ & $\mathrm{Sd}$ & $\begin{array}{c}\text { Mean } \\
\text { ranks }\end{array}$ & Median & $X^{2}$ \\
\hline \multirow[t]{3}{*}{ 1.SWFR } & Some & 17 & 14,00 & 3,16 & 25,74 & 16,00 & 2,38 \\
\hline & Mostly & 15 & 14,73 & 2,81 & 33,23 & & \\
\hline & Too much & 28 & 15,11 & 1,70 & 31,93 & & \\
\hline \multirow[t]{3}{*}{ 2. PE } & Some & 17 & 12,43 & 2,84 & 23,32 & 14,00 & 5,92 \\
\hline & Mostly & 15 & 13,06 & 2,63 & 28,50 & & \\
\hline & Too much & 28 & 14,22 & 1,61 & 35,93 & & \\
\hline \multirow[t]{3}{*}{ 3.SWRSO } & Some & 17 & 12,76 & 3,61 & 24,82 & 15,00 & 2,78 \\
\hline & Mostly & 15 & 14,00 & 3,20 & 31,70 & & \\
\hline & Too much & 28 & 14,55 & 2,03 & 33,30 & & \\
\hline \multirow[t]{3}{*}{ 4.SWL } & Some & 17 & 9,35 & 2,49 & 27,71 & 10,00 & 3,27 \\
\hline & Mostly & 15 & 9,33 & 2,02 & 25,80 & & \\
\hline & Too much & 28 & 10,36 & 1,63 & 34,71 & & \\
\hline \multirow[t]{3}{*}{ 5.TPSWB } & Some & 17 & 48,55 & 10,81 & 23,65 & 54,58 & 4,77 \\
\hline & Mostly & 15 & 51,13 & 9,23 & 29,40 & & \\
\hline & Too much & 28 & 54,25 & 5,40 & 35,25 & & \\
\hline \multirow[t]{3}{*}{ 6.EE } & Some & 17 & 17,52 & 5,38 & 18,62 & 21,49 & $12,32 * *$ \\
\hline & Mostly & 15 & 21,46 & 2,87 & 31,33 & & \\
\hline & Too much & 28 & 22,46 & 2,57 & 37,27 & & \\
\hline \multirow[t]{3}{*}{ 7.BE } & Some & 17 & 17,92 & 5,50 & 21,26 & 22,00 & $6,73^{*}$ \\
\hline & Mostly & 15 & 21,66 & 3,48 & 33,87 & & \\
\hline & Too much & 28 & 21,89 & 2,87 & 34,30 & & \\
\hline \multirow[t]{3}{*}{ 8.CE } & Some & 17 & 17,45 & 5,16 & 19,26 & 21,00 & $9,96 *$ \\
\hline & Mostly & 15 & 21,80 & 2,65 & 35,43 & & \\
\hline & Too much & 28 & 21,57 & 3,04 & 34,68 & & \\
\hline \multirow[t]{3}{*}{ 9.TPCE } & Some & 17 & 52,90 & 15,16 & 19,03 & 65,50 & $10,33 * *$ \\
\hline & Mostly & 15 & 64,93 & 7,99 & 34,00 & & \\
\hline & Too much & 28 & 65,92 & 7,59 & 35,59 & & \\
\hline \multirow[t]{3}{*}{ 10.IM } & Some & 17 & 18,72 & 4,12 & 23,03 & 21,65 & 4,64 \\
\hline & Mostly & 15 & 20,66 & 3,67 & 31,73 & & \\
\hline & Too much & 28 & 21,33 & 2,63 & 34,38 & & \\
\hline \multirow[t]{3}{*}{ 11.EM } & Some & 17 & 11,05 & 2,77 & 21,91 & 12,50 & $10,99 * *$ \\
\hline & Mostly & 15 & 11,46 & 3,31 & 25,73 & & \\
\hline & Too much & 28 & 13,76 & 1,95 & 38,27 & & \\
\hline
\end{tabular}




\begin{tabular}{llllllll} 
12.A & Some & 17 & 6,47 & 3,08 & 38,62 & 4,00 & $8,94 *$ \\
& Mostly & 15 & 3,93 & 1,98 & 21,57 & & \\
& Too much & 28 & 4,78 & 2,18 & 30,36 & & \\
\hline
\end{tabular}

Note: $* \mathrm{p}<.05 * * \mathrm{p}<.01 ; 1$. SWFR: Satisfaction with family relationships; 2 .

PE: Positive affection; 3. SWRSO: Satisfaction with relationships via significant others; 4. SWL: Satisfaction with life; 5. TPSWB: Total point of subjective well-being; 6. EE: Emotional engagement; 7. BE: Behavioural engagement; 8. CE: Cognitive engagement; 9. Total point of classengagement; 10. IM: Intrinsic motivation; 11. EM: Extrinsic motivation; 12. A: Amotivation

As shown in Table 3, with respect to the emotional engagement dimension, the Kruskal-Wallis test indicated that a significant difference existed between groups in which not-working children are involved in terms of school liking $(\chi 2=12.32, d . f .=2, p<.01)$. The Mann-Whitney U test was used to determine the difference between the groups. According to the results of the test $(U=71.50, p<.05)$, the difference was found to be between the group that like some (mean ranks $=18.62$ ) from school and the group that like mostly (mean ranks $=31.33$ ) from school. Additionally, according to the results of the test $(U=92.00, p<.01)$, the difference was found to be between the group that like some (mean ranks $=18.62$ ) from school and the group that like too much (mean ranks $=37.27$ ) from school. Moreover, according to the results of the test, no difference was found between the group that like mostly from school and the group that like too much from school.

As shown in Table 3, with respect to the behavioral engagement dimension, the Kruskal-Wallis test indicated that a significant difference existed between groups in which not-working children are involved in terms of school liking $\left(\chi^{2}=6.73, d . f .=2, p<.05\right)$. The Mann-Whitney U test was used to determine the difference between the groups. According to the results of the test $(U=131.00, p<.05)$, the difference was found to be between the group that like some (mean ranks $=21.26$ ) from school and the group that like mostly (mean ranks $=33.87$ ) from school. Moreover, according to the results of the test, no difference was found between the group that like mostly from school and the group that like too much from school. No difference was found between group that like some from school and the group that like too much.

As shown in Table 3, with respect to the cognitive engagement dimension, the Kruskal-Wallis test indicated that a significant difference existed between groups in which not-working children are involved in terms of school liking $\left(\chi^{2}=9.96, d . f .=2, p<.01\right)$. The Mann-Whitney U test was used to determine the difference between the groups. According to the results of the test $(U=57.00, p<.01)$, the difference was found to be between the group that like some (mean ranks $=19.26$ ) from school and the group that like mostly 
(mean ranks $=35.43$ ) from school. Additionally, according to the results of the test $(U=117.50, p<.01)$, the difference was found to be between the group that like some (mean ranks $=19.26$ ) from school and the group that like too much (mean ranks $=34.68$ ) from school. Moreover, according to the results of the test, no difference was found between the group that like mostly from school and the group that like too much from school.

As shown in Table 3, with respect to total points of the class engagement dimension, the Kruskal-Wallis test indicated that a significant difference existed between groups in which not-working children are involved in terms of school liking $\left(\chi^{2}=10.33, d . f .=2, p<.01\right)$. The Mann-Whitney U test was used to determine the difference between the groups. According to the results of the test $(U=61.00, p<.05)$, the difference was found to be between the group that like some (mean ranks $=19.03$ ) from school and the group that like mostly (mean ranks $=34.00$ ) from school. Additionally, according to the results of the test $(U=149.50, p<.05)$, the difference was found to be between the group that like some (mean ranks $=19.03$ ) from school and the group that like too much (mean ranks $=35.59$ ) from school. Moreover, according to the results of the test, no difference was found between the group that like mostly from school and the group that like too much from school.

As shown in Table 3, with respect to the extrinsic motivation dimension, the Kruskal-Wallis test indicated that a significant difference existed between groups in which not-working children are involved in terms of school liking $(\chi 2=10.99, d . f .=2, p<.01)$. The Mann-Whitney U test was used to determine the difference between the groups. According to the results of the test $(U=106.00, p<.01)$, the difference was found to be between the group that like some (mean ranks $=21.91$ ) from school and group that like mostly (mean ranks $=25.73$ ) from school. Additionally, according to the results of the test $(U=124.50, p<.05)$, the difference was found to be between the group that like mostly (mean ranks $=25.73$ ) from school and the group that like too much (mean ranks $=38.27$ ) from school. Moreover, according to the results of the test, no difference was found between the group that like same from school and the group that like mostly from school.

As shown in Table 3, with respect to the amotivation dimension, the Kruskal-Wallis test indicated that a significant difference existed between groups in which not-working children are involved in terms of school liking $(\chi 2=8.49, d . f .=2, p<.05)$. The Mann-Whitney $\mathrm{U}$ test was used to determine the difference between the groups. According to the results of the test $(U=63.50, p<.01)$, the difference was found to be between the group that like some (mean ranks $=38.62$ ) from school and the group that like mostly (mean ranks $=21.57$ ) from school. Moreover, according to the results of the test, no difference was found between the group that like mostly from school and the 
group that like too much from school. No difference was found between group that like some from school and the group that like too much. Finally, with respect to satisfaction with family relationships, positive affection, satisfaction with life, satisfaction with relationships via significant others, total points of subjective well-being and intrinsic motivation, no differences were found between the groups.

\section{Conclusion}

In this study, differences were found between the child labor group and non-working groups of students in terms of motivation to study, engagement in class and subjective well-being. With respect to child labor, as liking of school increased, subjective well-being, class engagement and motivation to study levels increased. Conversely, with respect to not-working children, as liking of school increased, class engagement and motivation to study levels increased.

Generally, evaluating the results of this study reveals that the children (child laborers) who work part-time in a job have lower levels of subjective well-being, class engagement, and motivation to study than do those children who do not work in a job. This result is generally consistent with the literature because the studies found that the levels of well-being of children who work part-time (child laborers), their academic motivation and engagement in class were lower than were the corresponding levels of those who did not work (Beegle, Dehejia \& Gatti, 2009; Biggeri, Libanora, Mariani \& Menchini, 2006; Biggeri \& Mehrotra, 2011; Dreze \& Kingdon, 2001; Estacio \& Marks 2005; Woodhead, 1999). Part-time work in a job adversely affects students in Turkey. This result appears to support universal explanations of the nature of being a working child (child laborers).

In this study, differences between the groups (child laborers and notworking children) in terms of extrinsic motivation and satisfaction with relationships via significant others were not found significant. The reason for this result might be sought in the nature of the relevant variables. For instance, extrinsic motivation is associated with rewarding and punishment (Deci \& Ryan, 1985). In both groups, punishment and reward are separate factors from the internal structures of individuals. The relationship with significant others is related to individuals such as relatives and friends (Eryilmaz, 2009). Relationships with parents and siblings are evaluated in terms of satisfaction with the relationships with the family. These factors are less likely to affect individuals because they are not included in the inner world of individuals. Consequently, there might be no difference between the groups due to the low importance of the related variables for individuals.

According to the results of the study, level of school liking for nonworking students is related to academic variables rather than to subjective 
well-being. This result can have two meanings. The first is that not-working children's subjective well-being was already high compared with the child laborers. The second is that a certain level of subjective well-being of these children might be a sign that they need not raise their subjective well-being in the school context.

Being a working child adversely affects the educational experiences of children. These negative effects lead children to attend school but decrease their motivation for school and lessons (Beegle, Dehejia \& Gatti, 2009; Dreze \& Kingdon, 2001). The findings of this study generally confirm the aforementioned effects for working children. When poverty is controlled in working children, the factor that is important in academic success is that the child likes school and is interested in lessons (Goulart \& Bedi, 2008).

The students who work in a job and who like school more were found to have higher motivation to study, class engagement and subjective wellbeing compared with other students who work in a job and who like school less. For working children (child laborers), the importance of liking school points to the concept of psychological resilience in the psychology literature. According to the psychological resilience model, for children, poverty and work in a job are considered environmental risk factors that adversely affect psychological resilience. Conversely, school is one of the environmental protection factors for psychological resilience (Masten, 1994; Masten \& Reed, 2002). In summary, if the working children's school liking levels increase, their subjective well-being, class engagement, and motivation to study also increase because liking school also means responding to the school's demands. Students who respond to these demands develop qualifications. In these conditions, the academic achievement of students who like school might increase. They experience low emotional problems and establish positive social relationships. Their psycho-social compliance might also increase (Masten, 1994; Masten \& Reed, 2002). In future, studies research on school liking and psychological resilience might be productive.

Applications: In addition, the satisfaction of working children (child laborers) with family relationships does not change depending upon whether they like the school, possibly because of the disorganized and disinterested families of working children (Walkerdine, 2005). Particularly in Turkey, the families of working children support their children in attending school due to legal necessity. If there is no legal obligation, the parents might want to take their children away from school during that time. These results indicate that families of working children must be supported by relevant institutions in economic, educational and psychological aspects and must be informed.

This study was conducted on non-working students and on part-time working students at a job. The results of the study showed the importance of liking school, particularly for working children. At this point, based on the 
results of the study, it is advisable to maintain a positive attitude toward school development programs for working and not-working children. In terms of social services, the results of this study revealed that working children's educational needs should not be neglected.

\section{References:}

1. Abu-Hilal, M. M. (2000). A structural model of attitudes towards school subjects, academic aspiration and achievement. Educational Psychology, 20(1), 75-84.

2. Beegle, K.,Dehejia, R. \& Gatti, R. (2009). Why should we care about child labor? The education, labor market, and health consequences of childlabor. Journal of Human Resources, 44(4), 871-889.

3. Biggeri, M., Libanora, R., Mariani, S. \& Menchini, L. (2006). Children conceptualizing their capabilities: results of a survey conducted during the first children's world congress on child labour. Journal of Human Development, 7(1), 59

4. Biggeri, M. \& Mehrotra, S. (2011). Child poverty as capability deprivation: How to choose domains of child well-being and poverty. In Children and the capability approach(pp. 46-75).

Palgra ve Macmillan, London.

5. Bilgın, R.(2009). Diyarbakır'da Sokakta Çalışan Çocuklar Üzerin Sosyolojik Bir Araştırma. Electronic Journal of Social Sciences, 8(27), 232-244.

6. Binder, M. \& Scrogin, D. (1999). Labor force participation and houshold work of urban schoolchildren in Mexico: Characteristics and consequences. Economic Development and Cultural Change, 48(1), 123-154.

7. Covington, M.V. (1998). Thewilltolearn: A guide for motivatingyoung people.UK: Cambridge University Press.

8. Deci, E. \& Ryan, R. M. (1985). Intrinsic motivation and selfdetermination in human Behaviour. New York: Plenum.

9. Dorman, P. (2008). Child labour, education and health: A review of the literature. Geneva: ILO.

10. Dreze, J. \& Kingdon, G. G. (2001). School participation in rural India. Review of Development Economics, 5(1), 1-24.

11. Eccles, J. (1983). Expectancies, values, and academic behaviors. In J. Spence (Ed.), Achievement and achievement motivation. San Francisco: Freeman.

12. Erdoğdu, M. Y. \& Oto, R. (2004).Sokakta çalışan ve çalışmayan çocukların atılganlık ve saldırganlık davranışları açısından karşılaştırılmaları. Kriz Dergisi, 12(3), 11-23. 
13. Erikson, E. H. (1968). Life cycle. International encyclopedia of the social sciences, 9, 286-292.

14. Eryilmaz, A. (2009). Ergen öznel iyi oluş ölçeğinin geliştirilmesi. Türk Eğitim Bilimleri Dergisi, 7(4), 975-989.

15. Eryilmaz, A. (2011). The relationship between adolescents' subjective well-being andpositive expectations towards future. The Journal of Psychiatry and Neurological Sciences, 24, 209-215.

16. Eryilmaz, A. (2012). A model of subjective well-being for adolescents in high school. Journal of Happiness Studies, 13(2), 275-289.

17. Eryılmaz, A. (2014). Üniversite öğrencileri için derse katılım ölçeklerinin geliştirilmesi.Uşak Üniversitesi Sosyal Bilimler Dergisi, 7 (2), 203-214.

18. Eryılmaz, A., \& Ercan, L. (2014). Ergenler için ders çalışmaya motive olma ölçeğiningeliştirilmesi. Başkent University Journal of Education, 1(1), 34-40.

19. Estacio, E. V. \& Marks, D. F. (2005). Child labour and the International Labour Organization's Convention 182: a critical perspective. Journal of health psychology, 10(3), 475-484.

20. Fredricks, J. A.,Blumenfeld, P. C. \& Paris, A. H. (2004). School engagement: Potential of the concept, state of the evidence. Review of educational research, 74(1), 59-109.

21. Fyfe, A. (1989) Child Labour. Cambridge: Polity Press.

22. Goulart, P. \& Bedi, A. S. (2008). Child labour and educational success in Portugal. Economics of Education Review, 27(5), 575-587.

23. Heady, C. (2003). The effect of childlabor on learning achievement. World Development, 31(2), 385-398.

24. Hobbs, S. \& Cornwell, D. (1986). Child labour: An underdevelopedtopic in psychology. International Journal of Psychology, 21(1-4), 225-234.

25. Li, Y. \& Lerner, R. M. (2011). Trajectories of school engagement during adolescence: implications forgrades, depression, delinquency, and substanceuse. Developmental psychology, 47(1), 233.

26. Martin, A. J. (2003). The Student Motivation Scale: Furthertesting of an instrument that measures school students' motivation. Australian Journal of Education, 47(1), 88-106.

27. Masten, A. S. (1994). Resilience in individual development: Successful adaptation despite risk and adversity. In M. C. Wang \& E. W. Gordon (Eds.), Educational resilience in inner-city America: Challenges and prospects (pp. 3-25). Hillsdale, NJ, US: Lawrence Erlbaum Associates, Inc. 
28. Masten, A. S. \& Reed, M. J. (2002). Resilience in development. (Ed: C. R. Snyder ve S. J. Lopez) The handbook of positive psychology (pp. 74-88). Oxford University Press.

29. Ravallion, M. \& Wodon, Q. (2000). Does child labour displace schooling? Evidence on behavioural responses to an enrollment subsidy. The economic journal, 110(462), $158 \quad 175$.

30. Ray, R. (2000). Analysis of child labour in Peru and Pakistan: A comparative study. Journal of population economics, 13(1), 3-19.

31. Rossi, M. \& Rosati, F. (2007). Impact of schoolquality on child labor and school attendance: The case of Conafe Compensatory Education Program in Mexico.

32. Santrock, J. W. (2006). Lifespan Developmental Psychology.

33. Skinner, E.Furrer, C., Marchand, G. \& Kindermann, T. (2008). Engagementand disaffection in the classroom: Part of a larger motivational dynamic?.Journal of educational psychology, 100(4), 765.

34. Tagay, Ö. \& Baltacı, H. Ş. (2017). Ergenlerde öznel iyi oluş ve zaman tutumu: Benlik saygısı ve iyimserliğin aracı rolü. Pamukkale Üniversitesi Ĕ̈itim Fakültesi Dergisi, $\quad$ 41(41), 131-144.

35. Uçan, A. \& Esen, B. K. (2015). Ergenlerin Öznel İyi Oluşlarının Toplumsal Konum İle İlgili Risk Alma Değişkenine Göre Incelenmesi. Mersin University Journal of the Faculty of Education, 11(2), 288-299.

36. Walkerdine, V. (2005). Developmental psychology and the study of childhood. Childhood: Critical Concepts in Sociology, 3, 13-25.

37. Wigfield, A. (1994). Expectancy-value theory of achievement motivation: A developmental perspective. Educational Psychology Review, 6, 49-78.

38. Woodhead, M. (1999). Combatting child labour: listen to what the children say. Childhood, 6(1), 27-49.

39. Yılmaz, A. G. F., Göçen, A. G. S., \& Y1lmaz, F. (2012). Sokakta çalışan ve çalışmayan ilköğretim öğrencilerinin sosyal bilgiler programındaki değerlere ilişkin algıları/perceptions of primary school 5th grade students' who are the child labour and who aren't at the street towardsvalues in social studies studi. E Uluslararası Eğitim Araştırmaları Dergisi, 4(1), 82-99. 